\title{
GROWTH OF MARBLE INDUSTRY AND LAND USE LAND COVER DYNAMICS IN RAJSAMAND TEHSIL, RAJASTHAN INDIA (1998-2018)
}

\author{
Rajesh Kumar Yadav ${ }^{1}$ and Seema Jalan² \\ ${ }^{1}$ Research Scholar, MLS University, Udaipur, Rajasthan, India \\ ${ }^{2}$ Professor \& Head, Department of Geography, MLS University, Udaipur, Rajasthan, India \\ Email: seemajalan1@gmail.com, rajesh.kumar201026@yahoo.com
}

How to cite this paper:

Yadav, Rajesh Kumar and Jalan, Seema (2021) Growth of Marble Industry and Land Use Land Cover Dynamics in Rajsamand Tehsil, Rajasthan India (1998-2018), Journal of Global Resources, Vol. 07 (02)

DOI:

10.46587/JGR.2021.v07i02.002

Received: 21 March 2021

Reviewed: 10 April 2021

Revised: 11 May 2021

Final Accepted: 21 May 2021

OPEN O A C ES S

Freely available Online www.isdesr.org
Abstract: Rajsamand tehsil is one of the major marbles producing regions in the state of Rajasthan. The tehsil contributes approximately 23 percent of marble production of the state. Predominance of limestone and dolomite rocks in the geological structure and facilitating transport connectivity has resulted in phenomenal and continuous growth of marble industry in the tehsil. The growth has been accompanied by significant land use/ land cover (LULC) change. Mapping and monitoring of LULC change is vital for land management and sustainable development. The paper examines the LULC change in Rajsamand tehsil context of growth of marble industry over a period of two decades from 1998 to 2018. Multi-temporal satellite data comprising USGS Landsat 5 TM images of 1998, Landsat 7 ETM+ image of 2008 and Landsat- 8 OLI image of 2018 has been used for LULC mapping. Mapping has been done using Supervised Classification using of Maximum Likelihood Classifier. Six LULC classes have been delineated - marble mining, agricultural land and built-up, scrub land, water bodies and waste/barren land, followed by post classification change detection. Comparative analysis of LULC distribution over the study period shows that rapid growth of the marble industry has resulted in positive change in the area under wasteland and built-up.

Keywords: Land Use/Land Cover, Remote Sensing and GIS, Marble Industry, Change Detection 


\section{Introduction}

Changes in land use and land cover (LULC) on the earth's surface are generally divided into two concepts: land use and land cover (Barnsley et al. 2001). Land cover, which is described by the distribution of vegetation, surface properties, and the topography of the earth. Land use covers both the way humans and their habitat usage (Chaudhary et al. 2008). Global land cover data sets that are accurate and up to date are required for a variety of global change research studies, including ecosystem assessment and environmental modelling (Giri et al. 2005). The importance of investigating LULC, its trends and patterns of change, and their consequences is a prerequisite for planning and sustainable natural resource management (Petit et al. 2001). Evaluation of LULC dynamics is critical for assessing global and regional ecosystem changes. LULC alterations show a clear connection between the man and his environment (Fayaz et al. 2020). LULC change has become a fundamental component of contemporary strategies for natural resource management and environmental monitoring (Kaul and Sopan 2012). "Change detection is the process by observing changes in the status of an object or phenomenon over time. It entails the capability of quantifying temporal effects through the use of multi-temporal datasets." (Othman et al. 2013; Singh, 1989). Accurate and timely change detection of the Surface of the earth's features is critical for comprehending the interaction and relationship between natural and human phenomena, as well as for promoting more effective decision-making (Lu et al. 2004). LULC changes occur rapidly in the vicinity of surface mining areas, causing serious environmental degradation to the landscape (Matejicek et al. 2010).

Significant research has in the past demonstrated that land management, planning, and sustainable development need to mapping and monitoring LULC changes. Several researches have shown that remote sensing technology is an effective tool for monitoring LULC changes and evaluating the impacts of mining on the environment. Digital change detection is known as a process to detect and express land use changes based on co-registered multi-temporal remote sensing data. (Moeletsi et al. 2017) have investigated the effectiveness of remote sensing technology in detecting land cover change caused by granite quarries in South Africa. (Basommi et al. 2015) examine the uses of geospatial techniques for the assessment of LULC dynamics of mining region in Wa east district of Ghana. (Borana et al. 2014) investigated the LULC change associated with a sandstone quarry in Jodhpur and discovered that mining activities led to significant land cover change. (Mouflis et al. 2008) used remote sensing, landscape metrics, and viewshed analysis to assess the environmental impact of marble quarries on the Greek island of Thasos. The marble quarries studied by (Koruyan et al. 2012) looked at the area expansion of their locations and changes in vegetation around the Mugla region between 2001 and 2009 by using remote sensing. "While remote sensing enables the observation of land surface changes, extracting information about those changes from satellite data requires effective and automated change detection techniques". (Roy et al. 2002). Analysing changes in land use and land cover can provide useful information for regional management and planning. Rapid, accurate, and dynamic monitoring of land use change is accomplished by RS and GIS (Mishra et al. 2019).

Marble is a gleaming stone renowned for its pleasing colours, smooth and uniform texture, moderate hardness, and gleaming polished surface with a silky feel. Their aesthetic value makes them unique among other dimensional stones. In geological terms, it is a metamorphosed limestone formed through recrystallization and thermal and regional metamorphism conditions. "Rajasthan distinguishes itself as having good quality marble as an Indian resource. 20 districts in one or the other form have marble from 33 districts". "Rajasthan alone accounts for approximately 89 percent of India and its processing capacity in the country 
is approximately 95 percent" (Indian Bureau of Mines, 2014). Makrana, Rajsamand, Udaipur, Abu Road, and Banswara are all significant processing centres in the state. The state has a capacity of around 1,000 million sq. $\mathrm{ft}$. and 3,000 million sq. ft. per year for marble slab and polished tiled production. In the state, various marbles are made, such as green marble, white marble, black marble and pink marble.

Rajsamand tehsil is one of the major marbles producing regions in the state of Rajasthan. The tehsil contributes approximately 23 percent of marble production of the State. Predominance of limestone and dolomite rocks in the geological structure and good transport connectivity has resulted in phenomenal and continuous growth of marble industry in the tehsil. The growth has been accompanied by significant LULC change. Thus, understanding the land cover dynamics in the region is vital for effective land management and sustainable development of the region. The present study investigates the LULC change over a period of two decades from 1998 to 2018 in Rajsamand tehsil and analyses the increase in marble mining area in context of its relationship with other LULC classes.

\section{Study Area}

Rajsamand tehsil is located in southern part of Rajsamand district covering 619 sq. $\mathrm{km}$ area extending between $24^{\circ} 56^{\prime} \mathrm{N}$ to $25^{\circ} 41^{\prime} \mathrm{N}$ latitude and $73^{\circ} 46^{\prime} \mathrm{E}$ to $74^{\circ} 03^{\prime} \mathrm{E}$ longitude. Physiographically, it is situated in Aravali basin. Geologically it comprises rocks of Aravali super group formed in lower Proterozoic age. The northern, north-eastern and south- western parts of the tehsil are occupied by Jharol, Dovda and Nathdwara group respectively. Climatically this region falls in sub-humid zone. The total population of the tehsil is 235140 persons (Census, 2011). The population is mainly dependent on agriculture and mining activity. Rajsamand tehsil is one of the largest marbles producing regions of the district. It contributes 62.08 percent of the total marble production of the district (Rajasthan District Survey Report, 2018-19). The marble of the tehsil is entirely dolomite and is being mined mainly in Kelwa, Janijhar, Umti, Tali, Morwad, Arna, Parvati etc. mines from Agaria, Kelwa Fort and Dholi Khan areas. These are mainly producing white marble. The location of the study area is shown in Figure 1.

As per the record of Mines and Geology Department of Rajasthan total 314 marble mines are operational in the tehsil. These marble mining and processing units provide employment to approximately one-tenth (22713 persons) of the population in Rajsamand circle (District Census Handbook of Rajsamand, 2011). Thus, marble mining constitutes the foundation of both the district and the State economies. However, the impact of mining on the environment and associated land use land cover changes cannot be overlooked.

\section{Materials and Methods}

For LULC mapping, multi-temporal satellite images (Landsat 5 Thematic Mapper Images (TM) from 1998, Landsat 7 Enhanced Thematic Mapper Plus (ETM+) from 2008, and Landsat 8 Operational Land Imager (OLI) from 2018) were obtained from the United States Geological Survey (USGS) Earth Explorer website (http://earthexplorer.usgs.gov/). All three datasets have a spatial resolution of $30 \times 30$ metres and use the Universal Transverse Mercator (UTM) Zone $43 \mathrm{~N}$ and WGS 84 datum. The selection of all three dry season images was made to best distinguish the spectral signatures of the various land cover types, particularly scrub and agriculture. Table 1 contains detailed information about the data.

Supervised classification of the three images has been done using the maximum likelihood classifier (MLC) algorithm. According to (Jonathan et al. 2006) "MLC is an ideal option as it is a very simple and effective method that is also extremely well-known and has been 
successfully applied to a wide variety of remote sensing problems." (Lillesand and Kiefer, 2000). Training sets have been identified based on the spectral signature of the various classes in False Color Composites (FCC) of corresponding images. For the training sets, different LULC classes' regions of interest $(\mathrm{ROI})$ were created. These $\mathrm{ROI}$ were used to train the classifier and assign them to different classes. To ensure the accuracy of the classified images, Google Earth Pro was used. It is the most important factor in determining the dependability of maps. Neither any image classification is completed until the accuracy of the classification has been determined (Kaul and Sopan 2012). On each of the three classified images, a sample of pixels was generated and compared to the ground reference data. Overall classification accuracy has been evaluated using the overall accuracy and kappa coefficient. Class wise accuracy has been assessed using the User's Accuracy (UA) and Producer's Accuracy (PA).

Table 01: Spectral Characteristics of Bands used for Classification

\begin{tabular}{|l|c|c|c|}
\hline Satellite & Acquisition Date & Band Used & Spatial Resolution \\
\hline Landsat 5 TM & 16 April, 1998 & $\begin{array}{c}\text { Red, NIR, SWIR-1 } \\
\text { (B3,B4,B5) }\end{array}$ & $30 \mathrm{~m}$ \\
\hline Landsat 7 ETM+ & 19 April, 2008 & $\begin{array}{c}\text { Red, NIR, SWIR-1 } \\
\text { (B3,B4,B5) }\end{array}$ & $30 \mathrm{~m}$ \\
\hline Landsat 8 OLI & 23 April, 2018 & $\begin{array}{c}\text { Red, NIR, SWIR-1 } \\
\text { (B4,B5,B6) }\end{array}$ & $30 \mathrm{~m}$ \\
\hline
\end{tabular}

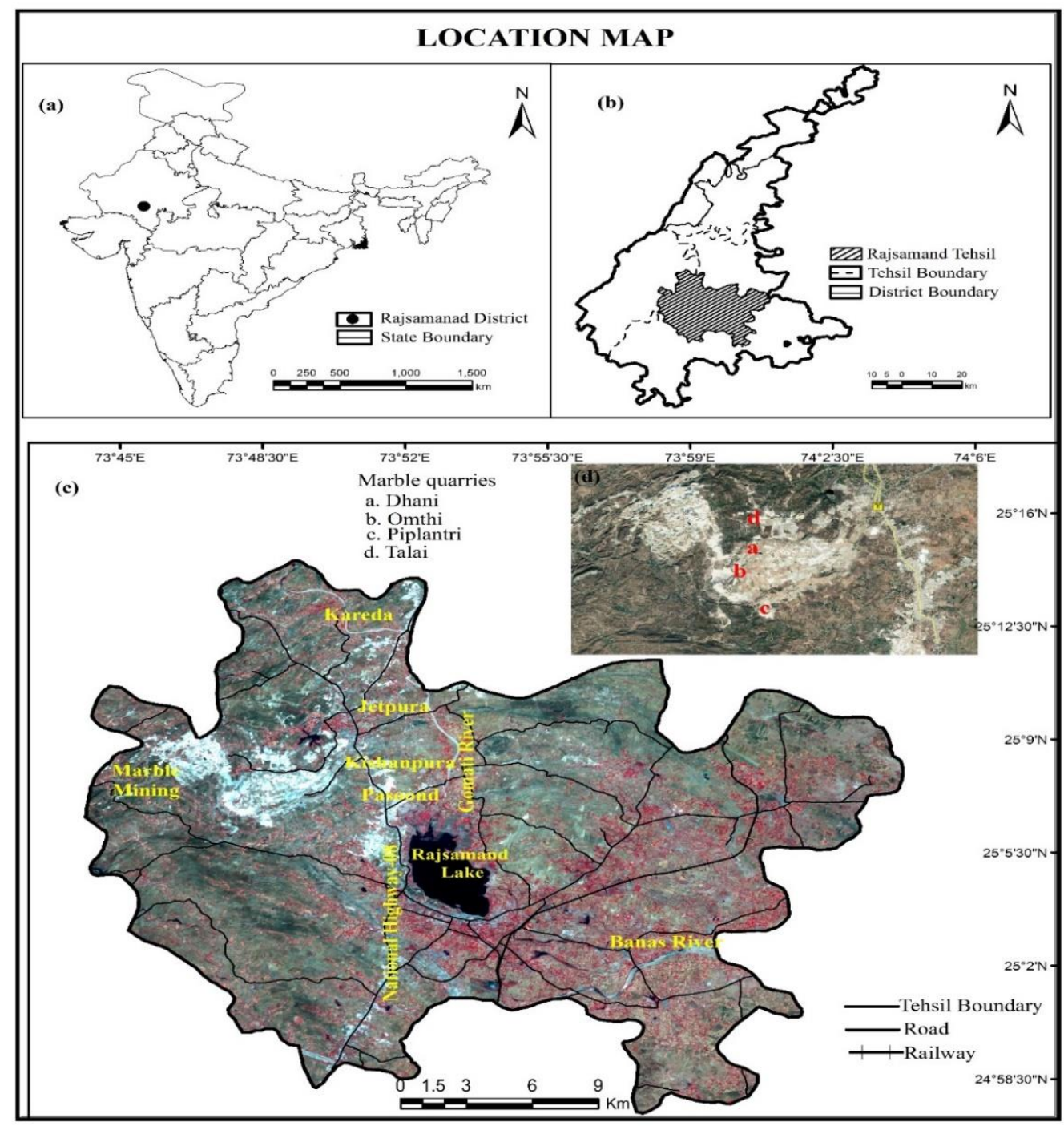

Figure 01: Location Map of the Study Area 


\section{Image Pre-Processing and Land Cover Classification Scheme}

Landsat 7 ETM+ 2008 image was line corrected in ENVI version 5.5. Red, NIR and SWIR-1 bands of all three satellite images were stacked for classification Specifications of selected bands of the three datasets used for classifications have been summarized in Table 1. Data subsets of the study area were extracted from all three images using a vector boundary map of Rajsamand tehsil generated in ArcGIS version 10.3. The classification scheme has been developed in accordance with the specific objectives of the present study and prior knowledge of the study area. Six major LULC classes based on Level-1 of the classification scheme prescribed by the National Remote Sensing Centre (NRSC) for Natural Resource Census (NRC) Land Use/Land Cover mapping on 1:50,000 scale (NRSC, 2014) has been chosen for classification. They are (a) agricultural land which includes cultivated and non-cultivated land (b) water bodies which comprise lakes, rivers and streams. (c) built-up land (d) wasteland/barren land which includes rocky and stony wasteland (e) marble mining which includes mines and processing units of marble, and (f) scrub comprising dense scrubland. After computation and analysis of LULC classes, post-classification change detection was performed for analysing the change in LULC classes over the last two decades. Change Matrix was generated for 1998 and 2008, 2008 and 2018 and 1998 and 2018 maps.

\section{RESULTS}

Spatial distribution of selected LULC classes for the year of 1998, 2008 and 2018 as obtained from the classification results has been shown in Figure 2, 3, 4 \& 5. Table 2 summarizes the area under different LULC categories in hectare and as percentage of total area of the tehsil.

\section{LULC Status 1998}

In 1998 the total marble mining area covered about 2874.78 hectare which comprising 4.80 percent of the total area. Table 2 shows that in year 1998 majority of the area was under agriculture land which was about 27175.53 hectare, constituting 45.40 percent of the total area. The area under scrub land was 18887.92 hectare comprising 31.56 percent of the total area. Whereas area under wasteland was about 8868.18 hectare (14.82 percent of the study area). Water and built-up land covered an area of 1412.42 hectare and 634.05 hectare respectively. In 1998 impact of anthropogenic activities was less reflected in the LULC of the study area.

\section{LULC Status 2008}

In 2008 total area under agriculture land was 21886.99 hectare $(36.57 \%)$ which shows decrement in area. Contrarily scrubland and wasteland has increased to 19284.65 hectares and 11490.54 hectare respectively. Marble mining area has also increased 4617.12 hectare, approx. double as compared to year 1998. The statistics also shows that the built- up and water covered about 1185.26 and 1388.32 hectare respectively. Table 2 provides a comparison of LULC composition of 1998 and 2008 with increment in the marble mining, scrubland, wasteland and built-up area, and decrement in area under agricultural land and water.

\section{LULC Status 2018}

In 2018 , the area under agriculture land has further decreased to 21332.27 hectare $(35.64 \%$ of total area of the tehsil). Scrubland comprises about 18384.27 hectare which is 30.72 percent of the area, slightly lower than 2008. On the other hand, water and built-up area cover about 1802.84 hectare $(3.01 \%)$ and 2069.01 hectare $(3.46 \%)$ respectively, which shows increment in both the land cover types. Area under marble mining has been continuously increasing since 1998. In 2018 marble mining area covers about 5985.37 hectare accounting 10\% of the total area of the tehsil. Wasteland covers about 10279 hectares, approx. 17 percent of the total area. 
Table 02: Area Under of LULC Classes in Rajsamand Tehsil (1998-2018)

\begin{tabular}{|l|c|c|c|c|c|c|}
\hline \multicolumn{1}{|c|}{ LULC Classes } & \multicolumn{2}{|c|}{$\mathbf{1 9 9 8}$} & \multicolumn{2}{c|}{$\mathbf{2 0 0 8}$} & \multicolumn{2}{c|}{$\mathbf{2 0 1 8}$} \\
\cline { 2 - 7 } & hectare & $\mathbf{( \% )}$ & hectare & $\mathbf{( \% )}$ & hectare & $(\%)$ \\
\hline Water & 1412.42 & 2.36 & 1388.32 & 2.32 & 1802.84 & 3.01 \\
\hline Built-up & 634.05 & 1.06 & 1185.26 & 1.98 & 2069.01 & 3.46 \\
\hline Agriculture & 27175.53 & 45.40 & 21886.99 & 36.57 & 21332.27 & 35.64 \\
\hline Marble Mining & 2874.78 & 4.80 & 4617.12 & 7.71 & 5985.37 & 10.00 \\
\hline Scrub & 18887.92 & 31.56 & 19284.65 & 32.22 & 18384.27 & 30.72 \\
\hline Wasteland/Barren & 8868.18 & 14.82 & 11490.54 & 19.20 & 10279.12 & 17.17 \\
\hline Total & $\mathbf{5 9 8 5 2 . 8 8}$ & $\mathbf{1 0 0}$ & $\mathbf{5 9 8 5 2 . 8 8}$ & $\mathbf{1 0 0}$ & $\mathbf{5 9 8 5 2 . 8 8}$ & $\mathbf{1 0 0}$ \\
\hline
\end{tabular}

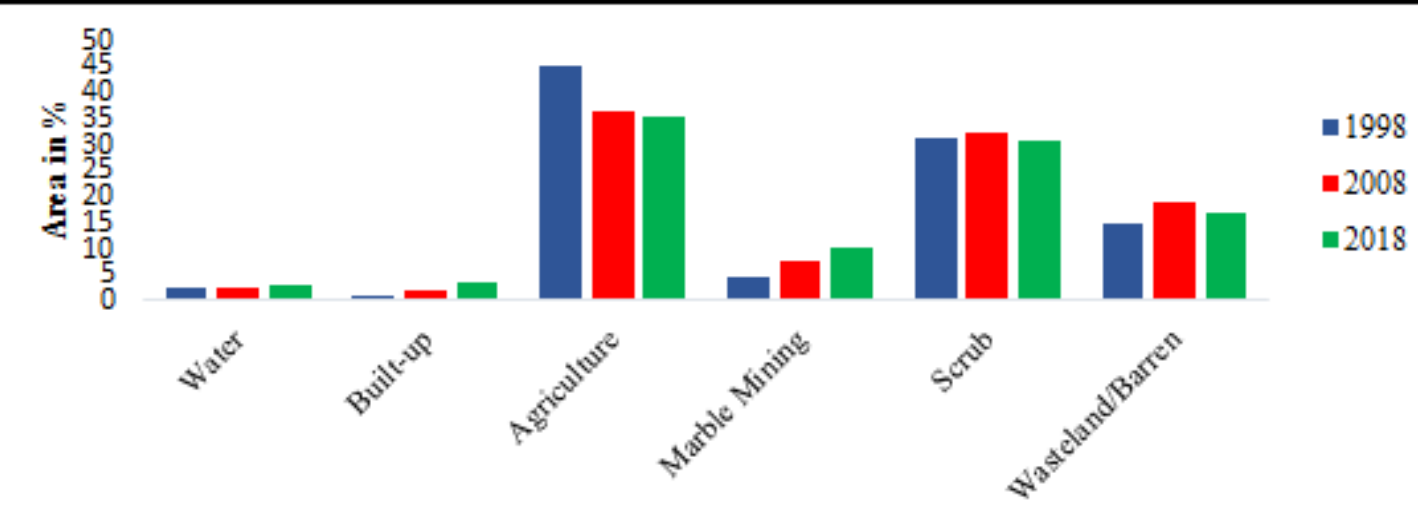

Area as percentage of total area of tehsil

Figure 02: Distribution of LULC in Rajsamand tehsil (1998, 2008 and 2018)

\section{Classification Accuracy Assessment}

Accuracy analysis becomes a critical component in land use land cover change detection analysis (Owojori and Xie, 2005). A stratified random sampling method has been employed to generate 180 sample points with minimum 30 points in each class on all three images of 1998, 2008 and 2018. Overall accuracy achieved for all three classified maps is above 90 percent. Overall Kappa statistics of 1998, 2008 and 2018 classification are 0.8803, 0.90 and 0.9068 respectively. Class-wise accuracy statistics for all 03 classified maps has been given in table 3 .

Table 03: Results of Accuracy Assessment of LULC Classified Images of Year 1998, 2008 and 2018

\begin{tabular}{|c|c|c|c|c|c|c|c|c|c|}
\hline \multicolumn{10}{|c|}{ Accuracy Assessment } \\
\hline Class Name & 1998 & 2008 & 2018 & 1998 & 2008 & 2018 & 1998 & 2008 & 2018 \\
\hline & $\begin{array}{c}\text { Producers } \\
\text { Accuracy } \\
(\%)\end{array}$ & $\begin{array}{c}\text { User } \\
\text { Accuracy } \\
(\%)\end{array}$ & Kappa & $\begin{array}{c}\text { Producers } \\
\text { Accuracy } \\
(\%)\end{array}$ & $\begin{array}{c}\text { User } \\
\text { Accuracy } \\
(\%)\end{array}$ & Kappa & $\begin{array}{c}\text { Producers } \\
\text { Accuracy } \\
(\%)\end{array}$ & $\begin{array}{c}\text { User } \\
\text { Accuracy } \\
(\%)\end{array}$ & Kappa \\
\hline Water & 96.67 & 96.67 & 0.96 & 100.00 & 96.67 & 0.9603 & 100 & 100.00 & 1.00 \\
\hline Built-up & 100 & 80.00 & 0.7692 & 100.00 & 90.00 & 0.8824 & 100 & 90.00 & 0.8824 \\
\hline Agriculture & 90.32 & 93.33 & 0.9195 & 78.79 & 86.67 & 0.8367 & 76.92 & 100.00 & 1.00 \\
\hline Marble Mining & 90.00 & 90.00 & 0.88 & 100.00 & 96.67 & 0.9603 & 96.55 & 93.33 & 0.9205 \\
\hline Scrub & 81.08 & 100.00 & 1.00 & 90.32 & 93.33 & 0.9195 & 90 & 90.00 & 88 \\
\hline Wasteland/Barrn & 92.31 & 80.00 & 0.7662 & 83.87 & 86.67 & 0.8389 & 100 & 80.00 & 0.7692 \\
\hline $\begin{array}{l}\text { Overall } \\
\text { Accuracy }\end{array}$ & \multicolumn{3}{|c|}{$90.00 \%$} & \multicolumn{3}{|c|}{$91.67 \%$} & \multicolumn{3}{|c|}{$92.22 \%$} \\
\hline Overall Kappa & \multicolumn{3}{|c|}{0.8803} & \multicolumn{3}{|c|}{0.90} & \multicolumn{3}{|c|}{0.9068} \\
\hline
\end{tabular}

As evident from Table 3, the UA of all classes in 1998 LULC map is greater than 90 percent, except built-up and wasteland/ barren which is 80 percent. This is due to 
misclassification of built up as on agriculture class. In 2008 classified image, the UA has been above 85 percent for all classes, and in 2018 it has been above 90 percent for all classes except wasteland/barren. High conditional kappa statistics and UA values indicate high reliability of classification results for all the three years.

\section{Land Use/Land Cover Change Detection}

The following sections present the results of post classification change detection for the study area from 1998 to 2018. Class to class change matrix has been generated for pairs of classified maps (1998-2008 and 2008 -2018) using the 'Matrix' tool in ERDAS Imagine version 14. Table 4 and 5 present the results for change matrix for the period 1998 to 2008, and 2008 to 2018 respectively.

\section{Year 1998 - 2008}

Table 4 shows that from 1998 to 2008 major changes have been observed in agriculture land of which about 4677.48 hectare area has been converted to wasteland. Notably 1505.43 hectare area of wasteland has changed to agricultural land. This change is mainly due to developed irrigational facility along the bank of Banas river. 213.39 hectares of agricultural land has changed to water class while 133.74 hectare area under water got converted to agriculture land. The reason for this change may be variability of rainfall. When there is surplus rainfall water level of the lake rises and spreads over agriculture land. When the rainfall is deficit the water level goes down leaving behind more area under agriculture land. Around 184.41 hectare area under marble mining got converted to wasteland while 910.56 hectare area of wasteland changed to marble mining during this period. About 578.79 hectare mining area has increased due to conversion of agricultural land. This is mostly observed between National Highway-8 and Gomti river. About 83.88 hectare area of water has changed into mining area. This marks the sites of marble waste dumping in Gomti river. Considering built up area, about 491 hectare area of agricultural land has been converted to the built-up area. This relates with urban sprawl of Rajsamand city and expansion of development activities in the tehsil. The conversion of 116.01 hectare area of built-up land to agriculture land may be result of classification errors.

\section{Year $2008-2018$}

During 2008 to 2018 the area under agricultural land has reduced about 13.38 percent due to conversion of some agricultural to wasteland. This may be attributed to lack of irrigational facility in north- eastern side of tehsil and proliferating mining activities in the study area. About 2.54 percent of agricultural land changed into mining class along $\mathrm{NH}-8$ and near Kelwa town (Figure 5). About 1.34 percent of agriculture land has changed to water, due to rising water level in Rajsamand lake and its extension over surrounding land. Approx. 961.56 hectare and 865.62 hectare area of marble mining has increased due to conversion from scrub land and wasteland respectively (Table 5). Change of marble mining area into water amounts to 65.9 hectare. This is due to formation of marble quarry lake in marble mining area (Box $G$ in Figure 5). Approx. 25.83 hectare area of water has been converted into marble mining due to marble slurry dumping in Gomti river. About 684.56 hectare land has been converted from scrub land to agriculture land. On the other hand, 1937.48 hectare of scrub land has changed to wasteland because of dumping of mining waste on scrub land. Due to spectral overlap between agricultural fallow land and built-up area classification errors have shown change of built-up into agricultural land. 
Table 04: LULC Change Matrix (1998 To 2008)

\begin{tabular}{|c|c|c|c|c|c|c|c|c|}
\hline \multirow{9}{*}{ 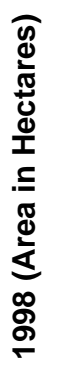 } & \multicolumn{8}{|c|}{2008 (Area in Hectares) } \\
\hline & LULC Class & $\begin{array}{c}\text { Agriculture } \\
\text { Land }\end{array}$ & $\begin{array}{c}\text { Built-up } \\
\text { Area }\end{array}$ & $\begin{array}{l}\text { Mining } \\
\text { Area }\end{array}$ & $\begin{array}{l}\text { Scrub } \\
\text { Land }\end{array}$ & $\begin{array}{l}\text { Wasteland } \\
\text { / Barren }\end{array}$ & $\begin{array}{l}\text { Water } \\
\text { Area }\end{array}$ & $\begin{array}{l}\text { Total } \\
1998\end{array}$ \\
\hline & Agriculture land & 18035.8 & 491 & 578.79 & 3179.07 & 4677.48 & 213.39 & 27175.53 \\
\hline & Built-up Area & 116.01 & 419.49 & 40.59 & 35.91 & 18.36 & 3.69 & 634.05 \\
\hline & Mining Area & 110.34 & 22.5 & 2405.07 & 134.37 & 184.41 & 18.09 & 2874.78 \\
\hline & Scrub land & 1985.67 & 151.74 & 598.23 & 13869.8 & 2247.11 & 35.37 & 18887.92 \\
\hline & Wasteland & 1505.43 & 97.83 & 910.56 & 2025.18 & 4322.18 & 7 & 8868.18 \\
\hline & Water Area & 133.74 & 2.7 & 83.88 & 40.32 & 41 & 1110.78 & 1412.42 \\
\hline & Total 2008 & 21886.99 & 1185.26 & 4617.12 & 19284.65 & 11490.54 & 1388.32 & 59852.88 \\
\hline
\end{tabular}

Table 05: LULC Change Matrix (2008 To 2018)

\begin{tabular}{|c|c|c|c|c|c|c|c|c|}
\hline \multirow{9}{*}{ 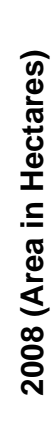 } & \multicolumn{8}{|c|}{2018 (Area in Hectares) } \\
\hline & LULC Class & $\begin{array}{l}\text { Agriculture } \\
\text { Land }\end{array}$ & $\begin{array}{l}\text { Built-up } \\
\text { Area }\end{array}$ & $\begin{array}{l}\text { Mining } \\
\text { Area }\end{array}$ & $\begin{array}{l}\text { Scrub } \\
\text { Land }\end{array}$ & $\begin{array}{c}\text { Wasteland } \\
\text { / Barren }\end{array}$ & $\begin{array}{l}\text { Water } \\
\text { Area }\end{array}$ & Total 2008 \\
\hline & Agriculture land & 15043.1 & 715.41 & 557.19 & 2346.7 & 2929.99 & 294.59 & 21886.99 \\
\hline & Built-up Area & 175.68 & 841.86 & 59.67 & 55.09 & 48.71 & 4.25 & 1185.26 \\
\hline & Mining Area & 395.34 & 98.82 & 3515.5 & 258.56 & 283 & 65.9 & 4617.12 \\
\hline & Scrub land & 3031.26 & 264.87 & 961.56 & 13027.62 & 1937.48 & 61.83 & 19284.65 \\
\hline & Wasteland & 2560.77 & 134.91 & 865.62 & 2676.36 & 5051.37 & 201.51 & 11490.54 \\
\hline & Water Area & 126.09 & 13.14 & 25.83 & 19.93 & 28.57 & 1174.76 & 1388.32 \\
\hline & Total 2018 & 21332.27 & 2069.01 & 5985.37 & 18384.27 & 10279.12 & 1802.84 & 59852.88 \\
\hline
\end{tabular}

\section{Discussion}

Careful study of the spatial distribution of LULC maps of Rajsamand Tehsil using multi-temporal datasets reveal remarkable change in LULC composition of the tehsil during the period of 20 years from 1998 to 2018. There has been a significant decrement in agricultural land by approximately 10 percent over the years, reducing to 35.64 percent in 2018 (Figure 5). Most of this reduction has occurred in eastern, north- eastern and around the Kelwa town which is apparently related to rapidly growing marble mining and processing activities in the study area. Between 2008 and 2018 marble processing units have grown continuously along NH- 8 along which agriculture land has decreased rapidly. On the other hand, in the eastern part of the tehsil agriculture land has decreased because of increased wasteland. These changes are associated with the change in social economic activity in the study area. In southern part of the tehsil substantial irrigation from Banas river and accessible plain area contribute to expansion in agricultural land. Therefore, most of the agricultural land underlies in the vicinity of the river because of which no noticeable change has been found in agricultural land in this area.

Figure 4 depicts an increase in scrub and wasteland cover in 2008. These classes together comprise about half of the total area in 2008 and 2018. The increase wasteland has been quite significant being approximately 05 percent. Wasteland has been expanding since 1998 in centre, north-eastern and eastern part of the tehsil. Major changes have been found between $\mathrm{NH}-8$ and Gomti river where marble processing has grown actively and continuously, resulting into consistent change of agricultural land into wasteland. In north-eastern and eastern part, the increase may be related to increasing mining activity, anthropogenic activity and lack of irrigation facility thus conversion of agriculture land into wasteland. The area under marble mining has steadily and significantly increased over the years, more than doubling in 2018 compared to 1998, but still accounts for approximately one tenth of the total area of the tehsil, as illustrated in Figure 3 and 5. The major marble mining site lies very close to Rajsamand city and Kelwa town within a distance of 02 to 06 kilometre in the north-west. This increase is because of spacious reserves of raw material, accessible cheap labour availability and high transport connectivity by $\mathrm{NH}-08$, which connects two major districts of Udaipur and Ajmer. Thus, 
the Rajsamand marble mining industry has been flourishing at a fast rate. In 1998 most of the marble mining sites were concentrated in western part of the tehsil i.e., Dhani, Nijharna, Kelwa, Talai, Jhanjhar and Kishanpura village contributed major part of marble production of the tehsil. But in 2008 and 2018 the major expansion of marble mining has been towards northern, northeastern and central part of the study area. New mining sites have developed including Miyari, Piplantri, Guleta, Atma, Podawali, Morwar, Pasoond and Parwat Kheri. From 1998 to 2018 marble processing units have continuously expanded from Rajsamand city to Kelwa town along $\mathrm{NH}-8$.

Built-up area has spread throughout the tehsil in rural areas. Higher concentration occurs in northern, central and north-western side of the tehsil. Since 1998 there has been a threefold increase in built up area (1.06 percent in 1998 to 3.46 percent in 2018) although it still covers less than 5 percent of the total area. This increase can be associated with mining industry and other socio-economic factors. Existing built-up areas are expanding to a greater extent including new built-up areas near by mining sites and around $\mathrm{NH}-8$ where marble processing units are flourishing. Area under water has also increased slightly less than three percent from 1998 to 2018. Major sources of water in the tehsil are Rajsamand Lake, Gomti, Thali and Banas rivers. Banas river flows in southern side of the tehsil which is major source of irrigation in the study area. Gomti river flows in northern part of the tehsil. Rajsamand lake is situated on Gomti river and is one of the major sources of drinking water for Rajsamand city as well as for the tehsil. In addition to this, some water bodies have also been detected around the marble quarries and western side of the Kelwa town. These marble quarry lakes are the result of marble excavations wherein water accumulates from rainfall and waste water generated from marble mining [Figure $5 \operatorname{Box}(G)]$.

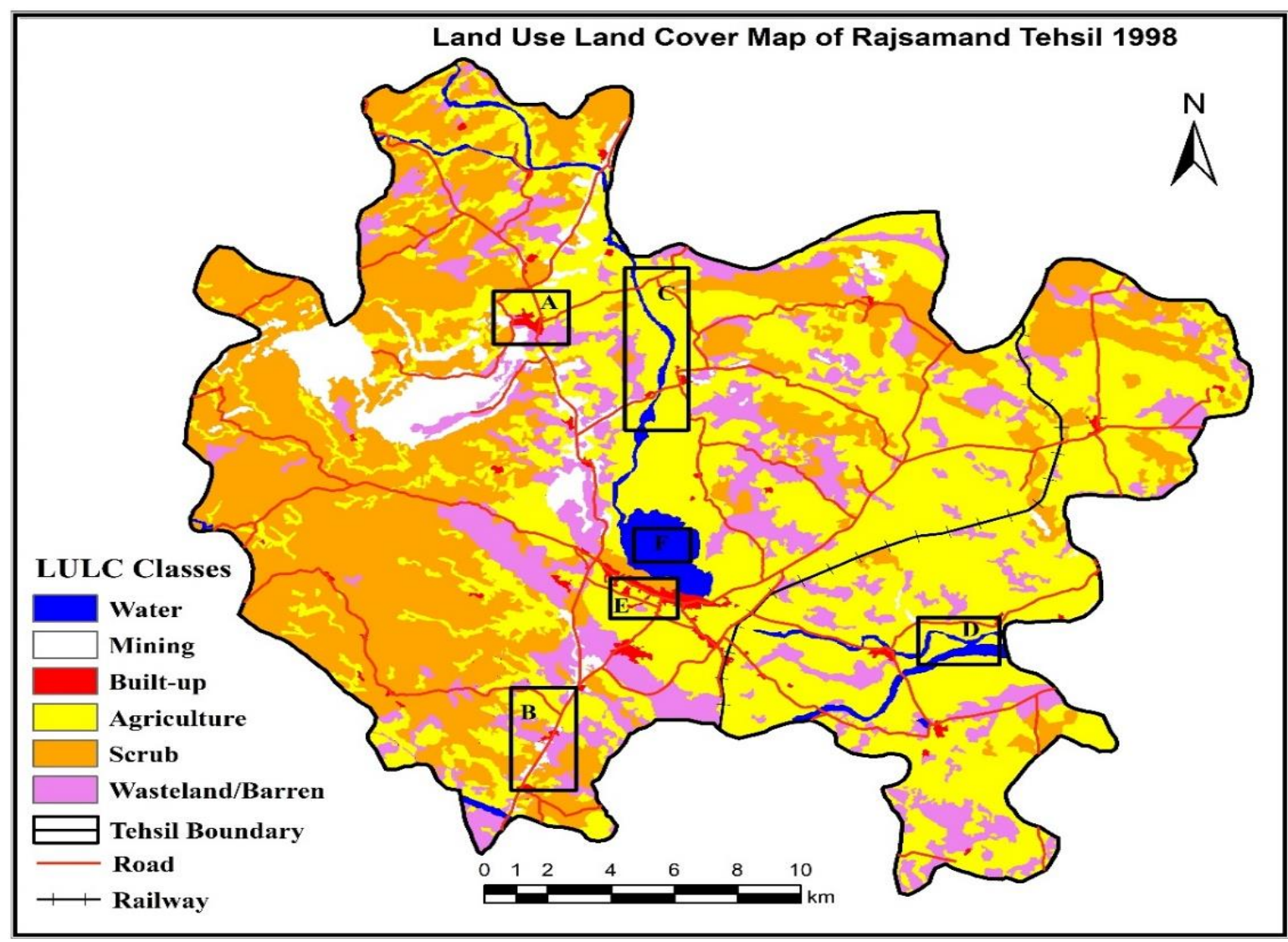

Figure 03: LULC composition of Rajsamand tehsil in 1998. Boxes A to F show important physical and cultural features of the tehsil - (A) Kelwa town (B) NH-08 (C) Gomti river (D) Banas river (E) Rajsamand city (F) Rajsamand lake. 


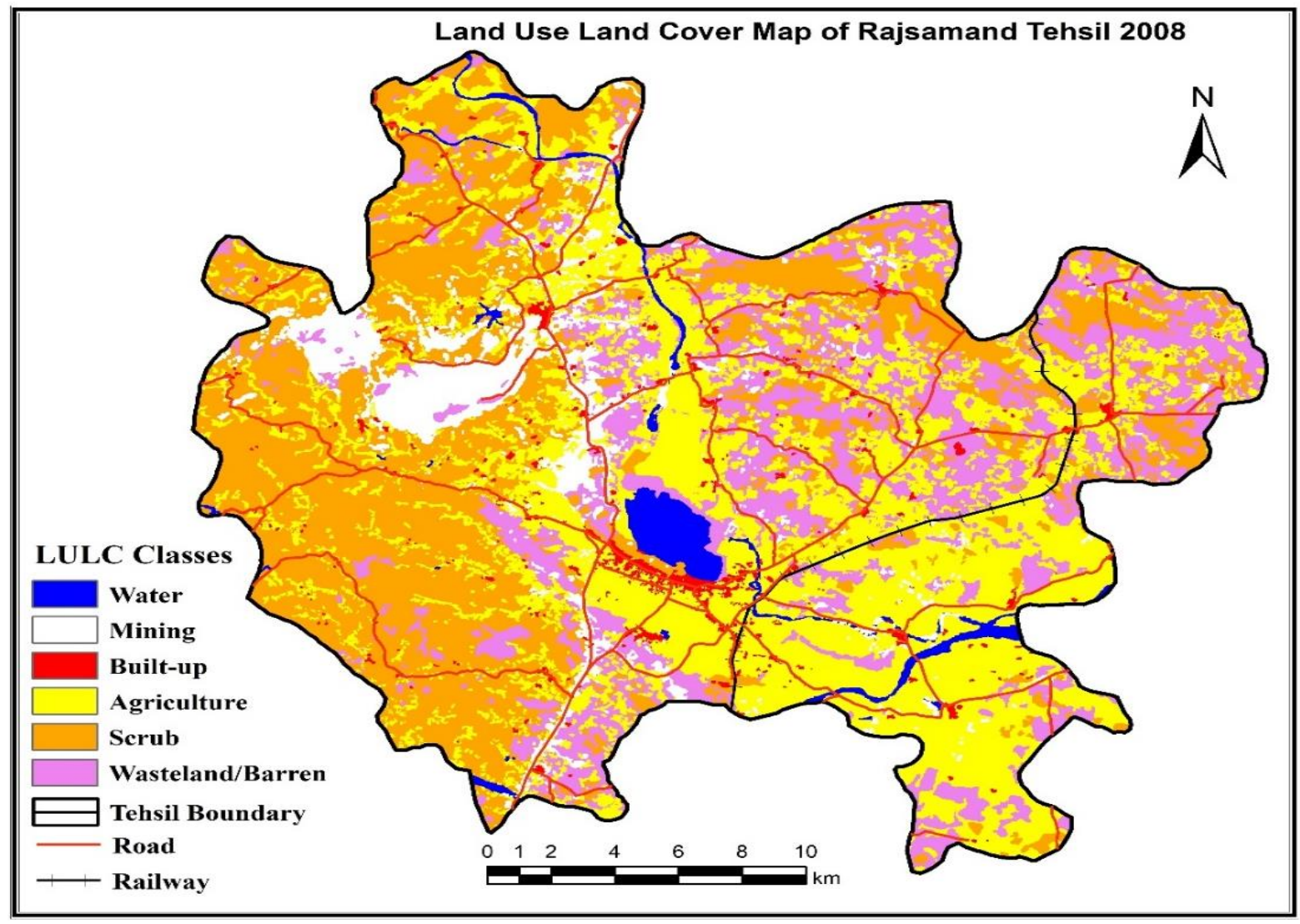

Figure 04: LULC composition of Rajsamand Tehsil in 2008

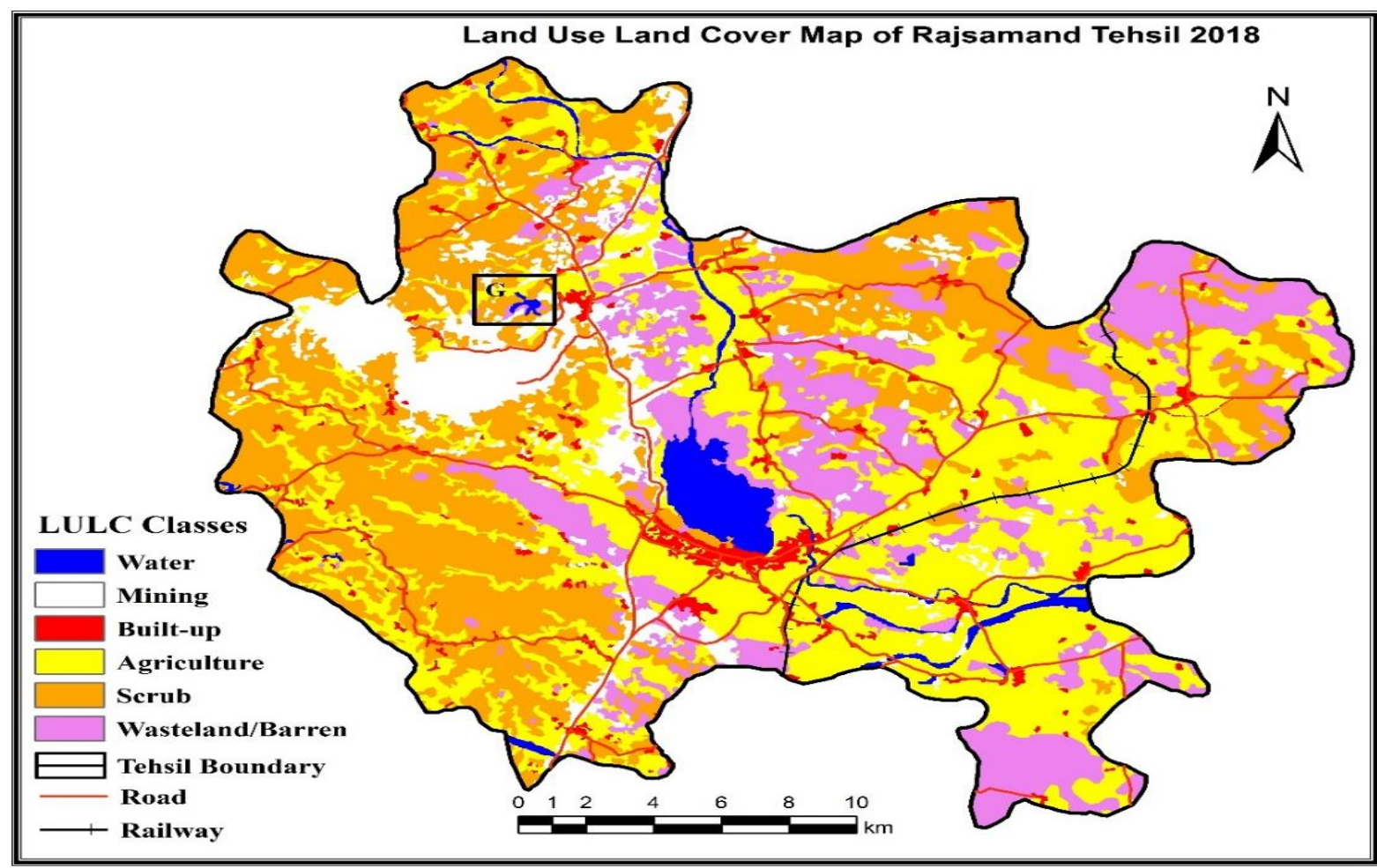

Figure 05: LULC composition of Rajsamand tehsil in 2018. Box (G) show Quarry Lake

\section{Overall Gain and Loss for the Period of 1998 to 2018}

Table 6 shows overall LULC change from 1998 to 2018. Changing complexion of LULC clearly reflects emerging economic activities in the region. Agriculture land is the predominant land cover in the study area and has also recorded greatest reduction extent in last two decades 
nearly about 5843.26 hectare (-21\%) from 1998 to 2018 . Despite of decreased area agriculture land has largest extent among all LULC classes in 2018. Largest expansion has occurred in built up area with a net increase of 226.32 percent (1434.96 hectare) indicating urban sprawl of Rajsamand city and emerging marble sector in the region. With an increase of about 108 percent (3110.59 hectare) marble mining area has undergone second highest increase. Increased wasteland by 15.91 percent (1410.94 hectare) over last two decades indicates that land degradation is to be taken into account along with economic development. Scrub land has decreased -2.67 percent ( -503.65 hectare) getting converted to wasteland and marble mining area.

Table 06: Overall Changes in LULC classes in each Period in Hectare

\begin{tabular}{|l|c|c|c|c|}
\hline LULC Class & $\begin{array}{c}\text { Net change in } \\
1998-2008\end{array}$ & $\begin{array}{c}\text { Net change in } \\
2008-2018\end{array}$ & $\begin{array}{c}\text { Overall changes in } \\
1998-2018\end{array}$ & $\begin{array}{c}\text { Net Growth rate in } \\
(\%)\end{array}$ \\
\hline Agriculture land & -5288.54 & -554.72 & -5843.26 & -21.50 \\
\hline Built-up Area & 551.21 & 883.75 & 1434.96 & 226.32 \\
\hline Mining Area & 1742.34 & 1368.25 & 3110.59 & 108.20 \\
\hline Scrub land & 396.73 & -900.38 & -503.65 & -2.67 \\
\hline Wasteland & 2622.36 & -1211.42 & 1410.94 & 15.91 \\
\hline Water Area & -24.1 & 414.52 & 390.42 & 27.64 \\
\hline
\end{tabular}

\section{Conclusion}

Mapping, monitoring and analysis of land use land cover change in Rajsamand tehsil is very essential for land management and sustainable development in a fast-emerging industrial area. LULC change caused by growth of marble industry in study area has been effectively mapped using three Landsat image of 1998, 2008 and 2018. The results establish the potential of remote sensing techniques in detecting land cover change. Since 1998, the dominant LULC class was agricultural land and scrub land but over the time there has been a significant loss of agricultural land. There has been continuous increase in marble mining over the two decades to cater the rapidly growing demand for marble. The marble mining has adversely affected the other LULC classes due to discharging of marble waste on agriculture land and other type of land. It has also affected soil productivity and caused deterioration in air and water quality. Marble industry is playing significant role in economic development of the tehsil and providing employment opportunities to the population. The findings raise concerns of decreased agriculture land in mining area and its influence on food security. The evaluation and conclusion of the study have a major policy implication in Rajsamand tehsil on sustainable land use practises.

\section{References}

1. Basommi, P., Guan, Q., and Cheng, D. (2015). Exploring Land Use and Land Cover Change in the Mining area of Wa East District Gana Using Satellite Imagery. Journal of De Gruyter Open, (1), pp. 618-626.

2. Barnsley, M., Moller, J., Barr, S. (2001). Inferring Urban Land Used by Spatial and Structure Pattern Recognition. Remote Sensing Urban Annals, pp.115-144.

3. Borana, S., Yadav SK., Parihar, SK., and Palria, VS., (2014). Impact Analysis of Sandstone Mines on Environment and Land Use Land Cover Features Using Remote Sensing and GIS Technique: A Case Study of Jodhpur City, Rajasthan, India. Journal of Environmental Research and Development. 8(3), pp. 796-804.

4. Chaudhary, B., Saroha, G. and Yadav, M. (2008). Human Induced Land Use/Land Cover Changes in Northern Part of Gurgaon District, Haryana, India: Natural Resources Census Concept. Journal of Human Ecology, 23(3), pp.243-252.

5. District Census Handbook of Rajsamand, (2011). Series-09 Part-XII-A Directorate of Census Operations Rajasthan.

https://censusindia.gov.in/2011census/dchb/0825_PART_B_DCHB_RAJSAMAND.pdf 
6. District wise Annual Mineral Report (2017-18). Department of Mines \& Geology, Udaipur, Government of Rajasthan.

7. Fayaz, A., Shafiq, M., Singh, H. and Ahmed, P. (2020). Assessment of spatiotemporal changes in land use/land cover of North Kashmir Himalayas from 1992 to 2018. Modelling Earth Systems and Environment, 6(2), pp.1189-1200.

8. Giri, C., Zhu, Z. and Reed, B. (2005). A comparative analysis of the Global Land Cover 2000 and MODIS land cover data sets. Remote Sensing of Environment, 94(1), pp.123-132.

9. Indian Minerals Yearbook, (2014). Part-III: Mineral Reviews 53rd Edition on Marble. Indian Bureau of Mines, Ministry of Mines, Government of India. https://ibm.gov.in/writereaddata/files/08092017100642Marble2015(Final).pdf

10. Jonathan, M., Meirelles, M., Berroir, JP., and Herlin, I. (2006). Regional Scale Land Use /Land Cover Classification Using Temporal Series of Modis Data. Journal of Revista Brasileira de Cartografia, 59, pp. 1-7.

11. Kaul, and Sopan, I., Harshika, A. (2012). land use land cover classification and change detection using High-Resolution Temporal Satellite Data. Journal of environment, 01(04), 146-152.

12. Koruyan, K., Deliormanli, A.H., Karaca, Z., Momayez, M., Lu, H., and Yalcin, E. (2012). Remote Sensing in Management of Mining Land and Proximate Habitat. Journal of South African Institute of mining and metallurgy. 112 (7), pp. 667-972

13. Lillesand, T., Kiefer, R. and Chipman, J. (2015). Remote sensing and image interpretation. 4th ed. Hoboken, NJ: Wiley.

14. Lu, D., Mausel, P., Brondízio, S., Eduardo, Moran, E. (2004). Change detection techniques. International Journal of Remote Sensing. VOL. 25, NO. 12, 2365-2407.

15. Matejicek, L. and Kopackova, V. (2010). Changes in Croplands as a Result of Large-Scale Mining and the Associated Impact on Food Security Studied Using Time-Series Landsat Images. Remote Sensing, 2(6), pp.1463-1480.

16. Mishra, P., Rai, A. and Rai, S. (2020). Land use and land cover change detection using geospatial techniques in the Sikkim Himalaya, India. The Egyptian Journal of Remote Sensing and Space Science, 23(2), pp.133-143.

17. Moeletsi, R. and Tesfamichael, S. (2017). ASSESSING LAND COVER CHANGES CAUSED BY GRANITE QUARRYING USING REMOTE SENSING. ISPRS - International Archives of the Photogrammetry, Remote Sensing and Spatial Information Sciences, XLII3/W2, pp.119-124.

18. Mouflis, G., Gitas, I., Iliadou, S. and Mitri, G. (2008). Assessment of the visual impact of marble quarry expansion (1984-2000) on the landscape of Thasos island, NE Greece. Landscape and Urban Planning, 86(1), pp.92-102.

19. Othman, A., Al-Saady, Y., Al-Khafaji, A. and Gloaguen, R. (2013). Environmental change detection in the central part of Iraq using remote sensing data and GIS. Arabian Journal of Geosciences, 7(3), pp.1017-1028.

20. Owojori, A., Xie, H. (2005). Landsat image-based LULC changes of San Antonio, Texas using advanced atmospheric correction and object-oriented image analysis approaches. Remote Sensing Image processing and Analysis (ES 6973)

21. Petit, C., Scudder, T. and Lambin, E. (2001). Quantifying processes of land-cover change by remote sensing: Resettlement and rapid land-cover changes in south-eastern Zambia. International Journal of Remote Sensing, 22(17), pp.3435-3456.

22. Roy, D., Lewis, P. and Justice, C. (2002). Burned area mapping using multi-temporal moderate spatial resolution data a bi-directional reflectance model-based expectation approach. Remote Sensing of Environment, 83(1-2), pp.263-286.

23. Rajasthan District Survey Report, Part-I (2018-19). 